\title{
STUDENTS’ PERCEPTION IN WRITING DESCRIPTIVE TEXT
}

\author{
Rizki Kurnia $^{1}$, Evie Kareviati ${ }^{2}$ \\ ${ }^{1,2}$ IKIP Siliwangi \\ ${ }^{1}$ rizkur@ student.ikipsiliwangi.ac.id, ${ }^{2}$ ekareviati@gmail.com
}

\begin{abstract}
In this study, the researcher used qualitative research method to find out students' perception in writing descriptive text. The subjects of this research were the 25 students in SMPN 32 Bandung. They were 13 boys and 12 girls. To collect the data, the researcher used pre-test, post-test that given after the students had got the treatment and also questionnaire. The result of the study showed the highest score for pretest was 84 , the lowest score was 16 , and the mean score was 43.2. The data showed that the students' score still low. And the highest score for post-test was 90, the lowest score was 40, and the mean score was 68.8. It means that students improved their ability after the treatment given, and their perception in writing descriptive text was found. But the researcher indicates that the students were still in low level or their ability in writing descriptive text was still weak.
\end{abstract}

Keywords: Students' Perception, Writing, Descriptive Text

\section{INTRODUCTION}

The teaching-learning process of English language concentrates on the four skills, thos are : reading, listening, speaking and writing (Pratiwi et al., 2019), and here is some statement of writing, the first is that writing is activity to write something in our mind to give idea, feelings, opinion or information in writing by using pencil, pen, marker and etc in the media paper or the others (Farizi \& Fauzyah, 2019). The second is that writing becomes successful when the reader catches a glimpse of the hidden speaker behind the text; when a phrase, a sentence, a few words reveal the human subject's intentions and presence (Nugraha \& Maryani, 2020). The third is Writing is about more than making our thoughts and ideas visible and concrete (Widayanti et al., 2019). It can be said that in writing, writers must have certain goals and intentions, certain relationships to their readers, and certain information to convey to the readers. Writing is considered as the most complicated skill to be mastered required not only great vocabularies but also grammar. However, writing in English is not easy and the students often find some difficulties while they are writing.

There are some texts that can be written, one of them is descriptive text. Descriptive text is the text that describes something. It is close to the learners' life. It is used to tell what or who a person is, place, or thing. A statement also said that a descriptive text usually has two main sections: first identification it is about how to introduction of a person, place, animal, or object will be described. And second it is about description of something such as animal, things, place or person by describing its feature, forms, colors, or anything related to what the writer describe. Descriptive text also has characteristic or language features such as adjectives and compound adjective dominant to used and using the simple present tense (Royani \& Sadiah, 2019). Students' perception can be observed, analyzed, and classified to be found out by the researcher. So, the researcher was interested in conducting this research based on the research problem: what students' perception in writing descriptive text is and what the causes of it are. One thing 
that can be done by teacher is to make a good perception in writing descriptive text to students, and one of the way to get it is to make the class becomes more interactive and involving themselves into the class's activities, especially in writing descriptive text. It is why the teacher should use an interesting strategy and an appropriate media.

\section{METHOD}

The researcher used qualitative descriptive methode as the research methodology. This is because the writer analyzed the data descriptively and the presentation of the result was in form of explanation of words which would be supported by data presented in the form of table. The goal of descriptive research is to describe a phenomenon and its characteristics, this research is more concerned with what rather than how or why something has happened. However, qualitative research is more holistic and often involves a rich collection of data from various sources to gain a deeper understanding of individual participants, including their opinions, perspectives, and attitudes (Royani \& Sadiah, 2019). In collecting data the researcher used tests and questionnaire. The tests that were given to students were pre-test and also post-test after the students had got the treatment. They were the seventh grade students in SMP Negeri 32 Bandung in academic years 2019-2020 consist of 25 students, to analyze students' perception in writing descriptive text.

\section{RESULTS AND DISCUSSION}

\section{Results}

This part discusses about the result of the analysis of the data. The data from pre-test and posttest and also questionnaire.

Table 1. Data of Pre-Test and Post-Test

\begin{tabular}{cccc}
\hline No & Sample & Pre-Test & Post-Test \\
\hline 1 & S1 & 48 & 80 \\
\hline 2 & S2 & 36 & 70 \\
\hline 3 & S3 & 36 & 55 \\
\hline 4 & S4 & 32 & 85 \\
\hline 5 & S5 & 36 & 60 \\
\hline 6 & S6 & 36 & 75 \\
\hline 7 & S7 & 84 & 90 \\
\hline 8 & S8 & 16 & 55 \\
\hline 9 & S9 & 32 & 55 \\
\hline 10 & S10 & 60 & 80 \\
\hline 11 & S11 & 80 & 80 \\
\hline 12 & S12 & 48 & 75 \\
\hline 13 & S13 & 36 & 65 \\
\hline 14 & S14 & 52 & 85 \\
\hline 15 & S15 & 76 & 90 \\
\hline 16 & S16 & 48 & 40 \\
\hline 17 & S17 & 52 & 55 \\
\hline 18 & S18 & 28 & 45 \\
\hline
\end{tabular}




\begin{tabular}{cccc}
\hline 19 & S19 & 56 & 90 \\
\hline 20 & S20 & 40 & 75 \\
\hline 21 & S21 & 32 & 75 \\
\hline 22 & S22 & 24 & 60 \\
\hline 23 & S23 & 20 & 60 \\
\hline 24 & S24 & 40 & 65 \\
\hline 25 & S25 & 32 & 55 \\
\hline Total & $\mathbf{2 5}$ & $\mathbf{4 3 . 2}$ & $\mathbf{6 8 . 8}$ \\
\hline
\end{tabular}

Table 2. The Result of Questionnaire

\begin{tabular}{|c|c|c|c|c|}
\hline No & Questions & Yes & Maybe & No \\
\hline 1 & Do you like learning English? & $100 \%$ & & \\
\hline 2 & $\begin{array}{l}\text { Do you like four English skills (listening, } \\
\text { speaking, writing, and reading)? }\end{array}$ & $51 \%$ & $23 \%$ & $26 \%$ \\
\hline 3 & Do you like writing? & $55 \%$ & $45 \%$ & \\
\hline 4 & $\begin{array}{l}\text { Do you think that writing is one of skills that } \\
\text { difficult to learn? }\end{array}$ & $12 \%$ & $53 \%$ & $35 \%$ \\
\hline 5 & $\begin{array}{l}\text { Do you understand the writing lesson using } \\
\text { teaching method that have been applied by } \\
\text { your teacher? }\end{array}$ & $66 \%$ & $34 \%$ & \\
\hline 6 & $\begin{array}{l}\text { By guidance of teacher, do you feel being } \\
\text { motivated to ask questions about things that } \\
\text { you have not understood yet? }\end{array}$ & $80 \%$ & $20 \%$ & \\
\hline 7 & $\begin{array}{l}\text { Does the teacher apply an appropriate } \\
\text { teaching method in each lesson? }\end{array}$ & $25 \%$ & $75 \%$ & \\
\hline 8 & Does the teacher use a media for teaching? & $93 \%$ & $7 \%$ & \\
\hline 9 & $\begin{array}{l}\text { Do you feel difficult to understand when } \\
\text { reading text? }\end{array}$ & $96 \%$ & & $4 \%$ \\
\hline 10 & Do you know descriptive text? & $82 \%$ & $7 \%$ & $11 \%$ \\
\hline 11 & $\begin{array}{l}\text { Do feel the difficulty when writing } \\
\text { descriptive text? }\end{array}$ & $91 \%$ & $9 \%$ & \\
\hline 12 & $\begin{array}{l}\text { Do you think the way of teacher in teaching } \\
\text { writing descriptive text is fun and effective? }\end{array}$ & $41 \%$ & & $59 \%$ \\
\hline 13 & $\begin{array}{l}\text { Do your parents always ask you about your } \\
\text { school activity? }\end{array}$ & $97 \%$ & & $3 \%$ \\
\hline 14 & Do your parents teach you English at home? & & & $100 \%$ \\
\hline 15 & $\begin{array}{l}\text { Have you ever spoken in English with your } \\
\text { friends or people around you? }\end{array}$ & $19 \%$ & & $81 \%$ \\
\hline
\end{tabular}

\section{Discussion}

In this research, the researcher used qualitative method to find out students' perception in writing descriptive text of 25 students. Before conducting the treatment, pre-test was given to students. The highest score was 84 , the lowest score was 16 , and the mean score was 43.2. The data showed that the students' score was low. After conducting the treatment, the highest score 
was 90 , the lowest score was 40 , and the mean score was 68.8 . It means that students improved their ability after the treatment had been given. But the researcher indicates that the students were still in low level. Their score is still below the minimum completeness criteria, which is 75.

From the data above, it was found that students' perception in writing was positive, even though they still had difficulty in it. It could be seen from the table above that $12 \%$ of the students said that writing is not one of skills that difficult to learn. $82 \%$ of respondents knew descriptive text but $91 \%$ of the respondents said that they felt the difficulty when writing descriptive text. The researcher could say that they had a problem with vocabulary as showed if $96 \%$ of them felt difficult to understand when reading text. It also happened because all of students weren't taught English at home by their parents and their experience in speaking English with their friends or people around is very less. But from the first question, all students were aware that they like English subject. It makes them easier to understand what material that the teacher teach. From number two and three of the questionnaires, we could see that most of the students like four basic skills especially writing. Although $45 \%$ of the students were still confused to answer the questions. They felt uncertain that they like writing skill.

\section{CONCLUSION}

The aim of this research was to know students' perception in writing descriptive text. The result of data showed that most of their score is still below the minimum completeness criteria, which is 75. Most of the students liked writing and knew what descriptive text is. From the questionnaire, it was shown that the teacher may have given students motivation to learn English and applied an appropriate teaching method. But the teacher didn't make students feel that descriptive text was fun, and also didn't make it effectively. It made students perceive that the teaching-learning process was not interesting. It also means that the teacher can find another way to teach effectively and make it to be more fun which make students easier to understand and get the point. Students should learn more about writing descriptive text especially about vocabulary that related with descriptive text and to enhance their ability in writing skill. So the research is expected to provide motivation and encourage other researchers to conduct further research and efforts to reveal the factors that research results can be more comprehensive. The results of this study are also expected to contribute to the development of English writing.

\section{ACKNOWLEDGMENTS}

Alhamdulillah all gratitude to Allah S.W.T who gave His blessing to researcher, so researchers can finish this article with a good health condition. First, for students as one of the learning resources to know the difficulties in writing descriptive text. Finally, researcher would like to thank all those who have helped for the incompatibility of this article Researcher really thanks for researchers' article supervisors who always gave researcher support when conducting this research. Also, researcher thanks to IKIP Siliwangi which gave the opportunity published this article. Also for a blind reviewer who reviewed this article as well as to the editorial team so this article can be published perfectly. 


\section{REFERENCES}

Ernawati, R., Purnomo, N. F., \& Suryani, L. (2019). An Error Analysis in Writing Descriptve Text of the Seventh Grade Students. Professional Journal of English Education, 616621.

Farizi, I., \& Fauzyah, F. (2019). The Use if Think Pair Share in Teaching Writing Descriptive Text. Professional Journal of English Education, 752-756.

Nugraha, B., \& Maryani. (2020). An Analysis of Students' Error in Writing Simple Sentences. Professional Journal of English Education, 49-53.

Pratiwi, R., Aulia, R. P., \& Suryani, L. (2019). An Error Analysis on Using Personal Pronouns in Writing Descriptive Text. Professional Journal of English Education, 608-615.

Sadiah, S., \& Royani, A. S. (2019). An Analysis of Grammatical Errors in Students' Writing Descriptive Text. Professional Journal of English Education, 764-769.

Widayanti, T., Rustyana, N., \& Haryudin, A. (2019). Students' Perception in Writing Procedure Text. Professional Journal of English Education, 687-691.

Yusuf, M., \& Hasanudin. (2020). The Implementation of Make a Match Method to Improve Writing Descriptive Text at Tenth Grade Students in SMK Jabir Al-Hayyan. Professional Journal of English Education, 259-265. 